\title{
Potential Drug Candidates Underway Several Registered Clinical Trials for Battling COVID-19
}

\author{
Fahmida Begum Mina ${ }^{\mathrm{a}}$, Md. Siddikur Rahman ${ }^{¥ a}$, Sabuj Das ${ }^{¥ a}$, Sumon Karmakar ${ }^{\mathrm{b}}$, Mutasim Billah ${ }^{\mathrm{c}^{*}}$ \\ ${ }^{a}$ Department of Genetic Engineering and Biotechnology, University of Rajshahi, Rajshahi-6205, Bangladesh \\ ${ }^{b}$ Molecular Biology and Protein Science Laboratory, University of Rajshahi, Rajshahi-6205, Bangladesh \\ 'Professor Joarder DNA \& Chromosome Research Laboratory, University of Rajshahi, Rajshahi-6205, Bangladesh
}

*Corresponding Author: Mutasim Billah, Professor Joarder DNA \& Chromosome Research Laboratory, University of Rajshahi, Rajshahi, Bangladesh

Corresponding Author Mail: mutasimbillahshazu@gmail.com

${ }^{¥}$ Co-second author

\begin{abstract}
The emergence of new type of viral pneumonia cases in China, on December 31, 2019; identified as the cause of human coronavirus, labeled as "COVID-19," took a heavy toll of death and reported cases of infected people all over the world, with the potential to spread widely and rapidly, achieved worldwide prominence but arose without the procurement guidance. There is an immediate need for active intervention and fast drug discovery against the 2019-nCoV outbreak. Herein, the study provides numerous candidates of drugs (either alone or integrated with another drugs) which could prove to be effective against 2019$\mathrm{nCoV}$, are under different stages of clinical trials. This review will offer rapid identification of a number of repurposable drugs and potential drug combinations targeting 2019-nCoV and preferentially allow the international research community to evaluate the findings, to validate the efficacy of the proposed drugs in prospective trials and to lead potential clinical practices.
\end{abstract}

Keywords: COVID-19; Drugs; 2019-nCoV; Clinical trials; SARS-CoV-2

\section{Introduction}

A new type of viral pneumonia cases occurred in Wuhan, Hubei Province in China, on December 31, 2019; named "COVID-19" on January 12, 2020 by the World Health Organization (WHO) [1]. Approximately, 115,224 people died as a result of the COVID-19 outbreak, 1,865,979 cases had been confirmed in 210 countries and territories till April 13, 2020. The fatality rate of COVID-19 remains under assessment [2]. However, infections of human coronavirus had resulted in lethal endemics, which include endemic SARS (Severe Acute Respiratory Syndrome) and MERS (Middle East Respiratory Syndrome) [3]. CoV infection 
begins with the interaction of the receptor binding domain located in the spike protein (S protein) and target receptor on the host cell surface, such as, Angiotensin Converting Enzyme 2 (ACE2) for SARS-CoV and Dipeptidyl Peptidase-4 (DPP4) for MERS-CoV [4]. Compared to SARS-CoV, the novel coronavirus (2019$\mathrm{nCoV}$ ) uses ACE2 as its host-entry receptor. Binding between the receptor-binding domain in S protein and the cellular receptor, mediates membrane fusion and starts the COVID-19 life cycle [5]. S protein on the viral membrane plays a critical role in virus entry and is the key antigenic factor responsible for inducing the immune response of the host [6]. For 2019-nCoV, in addition to knowing the COVID-19 Spike protein (S protein) sequences (GenBank: MN908947.3), there are no studies on how immunogenic this specific protein can go beyond surrogate comparisons to SARS and MERS, which restrict the possible capacity to generate a vaccine quickly [7].Since it is a respiratory syndrome that has never been seen before and with the potential to spread extensively and rapidly, it gained the attention of the world but without the manual of treatment and management [8].Several national and international research groups are working on vaccine production and drug repurposing to prevent and treat the $2019-\mathrm{nCoV}$, but successful vaccines and drugs are still not available. Active prevention and drug discoveries approaches for the 2019-nCoV outbreak are urgently needed [9] [10]. This review will offer an accumulate information to the scientific research community about numerous potential candidates of repurposable drugs that can provide a synergistic effect in potentially treating 2019-nCoV/SARS-CoV-2.

\section{Drug candidates and their progression against 2019-nCoV}

As 2019-nCoV has labelled ongoing pandemic, causing a heavy toll of death due to its rapid transmission, the discovery of drugs against $2019-\mathrm{nCoV}$ is therefore a very urgent priority. However, there are no successful drugs currently targeted for 2019-nCoV / SARS-CoV-2. Drug repurposing, representing from existing drugs as an active drug development approach, could cut the time and reduce the cost compared to de novo drug discovery. Following is the accumulated information of potential candidates of drugs screened against 2019-nCoV/SARS-CoV-2.

\section{Remdesivir}

Remdesivir (GS-5734) is an adenine derivative phosphoramidate prodrug with a chemical structure similar to that of tenofovir alafenamide, an approved inhibitor of HIV reverse transcriptase. Remdesivir has broadeffects in cell cultures and animal models against RNA viruses, such as - MERS and SARS, and has been checked for Ebola in a clinical trial. A recent research confirmed that Remdesivir inhibited 2019-nCoV, when tested in concentrations of $\mathrm{EC} 50=0.77 \mu \mathrm{M}$ in Vero E6 cells [10] One US patient with 2019-nCoV was reported to get recovered after receiving intravenous remdesivir in January 6, as trials in patients with 2019-nCoV (NCT04252664 and NCT04257656) were initiated in early February to evaluate intravenous 
Remdesivir (200 mg on day 1 and $100 \mathrm{mg}$ once daily for 9 days), with estimated completion dates in April 2020 [11]. Notably, Remdesivir (EC50 = $0.77 \mu \mathrm{M}$; CC50 > $100 \mu \mathrm{M}$; SI > 129.87) at low-micromolar concentration, effectively blocked virus infection and showed high SI [12]. Preliminary data suggested that Remdesivir also effectively blocked virus infection in a human cell line (Huh-7 cells of human liver cancer), which is immune to 2019-nCoV and currently, it is in the Phase III of clinical trial established by China.

\section{Favipiravir}

Favipiravir (T-705), a guanine analogue, effectively inhibits the RNA-dependent RNA polymerase of RNA viruses such as influenza, Ebola, yellow fever, chikungunya, norovirus and enterovirus, adding a recent study, reported its activity against 2019-nCoV [10]. Patients with 2019-nCoV are being recruited in randomized trials to evaluate the efficacy of favipiravir plus interferon- $\alpha$ (ChiCTR2000029600) and favipiravir plus baloxavirmarboxil (an approved influenza inhibitor targeting the cap-dependent endonuclease) (ChiCTR2000029544) [13]. Although, EC50 value of Favipiravir in Vero E6 cells was as high as $67 \mu \mathrm{M}$. It was reported to reduce viral infection of 2019-nCoV in (EC50 $=61.88 \mu \mathrm{M}, \mathrm{CC} 50>400$ $\mu \mathrm{M}, \mathrm{SI}>6.46$ ) concentrations [14] suggesting further in vivo studies to be screened against 2019-nCoV to test the efficacy of this antiviral nucleoside.

\section{Ribavirin}

Ribavirin is a guanine derivative approved for treating Human coronavirus (HCV) and respiratory syncytial virus (RSV), evaluated in patients with SARS and MERS, but it has side effects, such as anaemia might prove severe at high doses [12] and whether it could offer sufficient potency against 2019-nCoV is uncertain [15]. Ribavirin, in high concentrations such as (Half- Effective Concentration (EC50) $=109.50 \mu \mathrm{M}$, HalfConcentration $(\mathrm{CC} 50)>400 \mu \mathrm{M}$, Selectivity Index (SI) > 3.65) was needed to minimize viral infection [10] and, according to preliminary results, may prove to be resistance to COVID-19.

\section{Pyrazofurin}

Pyrazofurin (Pyrazomycin) is a natural product present in Streptomyces candidus, a Ribavirin derived nucleoside analog. It has antibiotic, antiviral, and anti-cancer properties but due to extreme side effects, it was not effective in human clinical trials. Nevertheless, it continues to be the focus of ongoing research as a possible 2019-nCoV drug, or as a blueprint for improved synthetic derivatives [16-22]. 


\section{Chloroquine}

Chloroquine, a commonly used anti-malarial and autoimmune disease medication, has recently been identified as a potential wide-spectrum antiviral drug [23-24]. Chloroquine is known to block infection with the virus by growing the endosomal $\mathrm{pH}$ needed for virus / cell fusion, as well as interfering with the glycosylation of SARS-CoV cell receptors [25]. In addition to its antiviral activity, chloroquine has an immune-modulating activity which can synergistically increase its in vivo antiviral impact. Following the discovery in China of in vitro chloroquine activity against SARS-CoV-2, 50\% and 90\% effective concentrations of Vero E6 cells $(\mathrm{EC} 50=1,13 \mu \mathrm{M}$ and $\mathrm{EC} 90=6,90 \mu \mathrm{M})$ were discovered during culture tests[12]. Chloroquine, an authorized immune modulator, shows inhibitory activity against 2019-nCoV (EC50 $=1.13 \mu \mathrm{M}$ in Vero E6 cells) [26] and is tested in an open-label trial (ChiCTR2000029609) [27].

\section{Hydroxychloroquine}

Hydroxychloroquine (HCQ) sulfate, a derivative of Chloroquine (CQ), was first synthesized in 1946 by inserting a hydroxyl group into CQ and was shown to be much less ( 40\%) toxic than CQ in animals [13]. More significantly, HCQ is now commonly available for the treatment of autoimmune diseases such as systemic lupus erythematosus and rheumatoid arthritis. Since CQ and HCQ share similar chemical structures and mechanisms to serve as a weak base and immune-modulator, the idea that HCQ may be a potent candidate for treating SARS-CoV-2 infection is simple to conjure up [28]. As of 23 February 2020, seven registries of clinical trials have been listed in the Chinese Clinical Trial Registry (http:/www.chictr.org.cn) to use HCQ for COVID-19 diagnosis. The experimental evidence still lacks whether HCQ is as effective as CQ in the treatment of SARS-CoV-2 infection [29]. Hydroxychloroquine on viruses is generally the same as chloroquine because the action mechanism of these two molecules is similar, so researchers are more inclined to administer hydroxychloroquine for long periods, which will therefore be the first option in the treatment of SARS-CoV-2.

\section{Angiotensin Converting Enzyme 1 (ACE1)}

Angiotensin Conversion Enzyme 1 inhibitors (ACE-1 inhibitors), such as enalapril and ramipril, and angiotensin receptor antagonists (colloquially known as angiotensin blockers or ARBs), such as candesartan and valsartan, could be of use in the prevention and treatment of the symptoms of coronavirus SARS-CoV2(also known as 2019-nCoV), the cause of the infection known as COVID 19 [30]. At the moment (as of 21 March 2020) three related trials are listed on the ICTRP website of the WHO, the International Clinical Trials Registry Portal, as being planned or under way in China. The first, entitled "Clinical characteristics difference between patients with and without ACE1 treatment with 2019-nCoV infection in China" was 
published on 12 February and is stated to be recruiting; it is also listed on clinicaltrials.gov. The other two are not recruiting: "Recombinant human angiotensin-converting enzyme 2 (rhACE2) as a treatment for COVID-19 patients" (registered on 21 February but identified as withdrawn on clinicaltrials.gov) and "Clinical research on the effects of ACEIs / ARBs on novel coronavirus pneumonia (CoVID-19) infection" (registered on 2 March) [31].

\section{Angiotensin Converting Enzyme 2 (ACE2)}

ACE2 is one of the key receptors for SARS-CoV invasion of the human body [32]. Researchers found that SARS-CoV-infected or recombinant wild-type SARS-spike protein-treated mice displayed significantly reduced ACE2 expression in the lung. It has also been shown that the latest outbreak of coronavirus pneumonia (2019-nCoV, SARS-CoV-2) is invading human alveolar epithelial cells and is therefore, could be screened against 2019-nCoV, suggesting further studies [33].

\section{Non-Steroidal Anti-inflammatory Drugs (NSAIDs)}

Recent analysis of case-control studies indicates that NSAIDs are associated with higher rates of complications following respiratory tract infections, including complicated pneumonia, pleural effusions, chronic disease, peritonsillary abscess, spread or suppuration of infection to more than one site [34]. NSAIDs have also been associated with delays in prescribing effective antibiotic treatment to patients requiring admission to hospital. The Food and Drug Administration (FDA) has released a statement on the use of non- anti- drugs (NSAIDS) in patients with 2019-nCoV. There are insufficient clinical evidences to link the use of NSAIDs in worsening COVID-19 symptoms, according to the agency [35].

\section{Ibuprofen}

Ibuprofen is a propionic acid-derived non-steroidal anti-inflammatory drug (NSAID), and is known to be the first propionic. Theformula of Ibuprofen is 2-(4-isobutylphenyl) propionic acid, originally discovered in 1960, while looking for a safer alternative of aspirin. Ibuprofen was eventually patented in 1961, and this drug was first introduced in the UK in 1969 and in the USA in 1974 against rheumatoid arthritis. It was the first NSAID available over the counter [36]. The ibuprofen is given as a racemic mixture on the available drugs. The R-enantiomer, undergoes comprehensive interconversion to the $\mathrm{S}$-enantiomer in vivo through the action of racemase alpha-methylacyl-CoA, when its administered. It is commonly proposed; in particular, that the $\mathrm{S}$-enantiomer is capable of generating greater pharmacological activity than the Renantiomer [35], and its ability against 2019-nCoV is unclear and could be screened for further analysis. 


\section{Umifenovir}

Umifenovir, an indole-based, hydrophobic, dual-acting active antiviral / host-targeting agent, used for influenza and other respiratory infections treatment and prophylaxis. The ability of Umifenovir to exert antiviral effects across several mechanisms has led to extensive work into its use for a number of enveloped and non-enveloped RNA and DNA viruses, including Flavivirus, Zika virus, Foot-and-mouth disease, Lassa virus, Ebola virus, Herpes simplex, Hepatitis B and C virus, Chikungunya virus, Reovirus, Hantaan virus and Coxsackie virus B5 [38]. Umifenovir is currently being investigated in conjunction with currently available and investigational HIV therapies as a potential treatment and prophylactic agent for COVID-19 caused by SARS-CoV2 infections [37].

\section{Nafamostat mesylate}

Nafamostat mesylate, a synthetic serine protease inhibitor, that contains antiviral and anti-cancer properties, used to treat acute pancreatitis. It is a powerful MERS- inhibitor that obstructs membrane fusion, was found inhibitive to 2019-nCoV infection when tested in EC50 $=22,50 \mu \mathrm{M}, \mathrm{CC} 50>100 \mu \mathrm{M}, \mathrm{SI}>4,44$ concentration rate, suggested for further studies [10]. As per the researchers at the University of Tokyo, Nafamostat will prevent the fusion of the virus envelope with the host cell surface proteins, the first step in infection with SARS-CoV-2 at one-tenth of the concentration provided by Camostat mesylate (Foypan), which was recently described by a German group as a SARS-CoV-2 inhibitor [39].

\section{Nitazoxanide}

It is a commercial antiprotozoal agent with an antiviral capacity against a wide range of viruses, including human and animal coronaviruses, reported to be resistance to 2019-nCoV, at low micromolar concentrations, such as - EC50 $=2.12 \mu \mathrm{M}$; CC50 > $35.53 \mu \mathrm{M}$; SI $>16.76$ [10]. Further in vivo evaluation of this medication is suggested against 2019-nCoV infection. Authorized for diarrhea therapy, Neitazoxanide has the potentiality to inhibit $2019-\mathrm{nCoV}$ and thus, needs clinical trials to determine the antiviral efficacy of this drug [12] [15].

\section{Oseltamivir}

Oseltamivir is a neuraminidase antiviral agent used to treat and prophylaxis influenza virus A (including pandemic H1N1) and B infection. Oseltamivir exercises its antiviral function by inhibiting the function of the viral neuraminidase enzyme located on the virus surface, which inhibits host cell budding, viral replication, and infectivity [37]. According to the CDC, data from clinical trials and observational studies have shown that early antiviral therapy can shorten the length of symptoms of fever and illness, and reduce 
the risk of other health complications (including pneumonia and respiratory failure).Oseltamivir is being screened against 2019-nCoV and is undergoing clinical trial [40].

\section{TMC-310911}

TMC-310911 (also known as ASC-09) is a novel investigational protease inhibitor (PI) that has been investigated for use in HIV-1 infections and is structurally similar to the darunavir. TMC-310911 has demonstrated potential activity against a number of HIV-1 strains, including multi-PI-resistant strains, and may be less likely to produce resistance, making it a potentially suitable therapy for patients who are both native to care and experienced with PI. The Hangzhou-based Ascletis Pharma, applied to the Chinese authorities in January to study Ritonavir and TMC-310911 (two HIV protease inhibitor) in clinical trials for treatment of COVID-19. TMC-310911 as a possible therapy for COVID-19 caused by SARS-CoV-2 in conjunction with other HIV therapies and antivirals.TMC-310911 is currently being investigated, in combination with other HIV therapies and antivirals, as a potential treatment for 2019-nCoV [41][42].

\section{Lopinavir and Ritonavir}

In patients infected with 2019-nCoV, clinical trials (e.g., ChiCTR2000029539) were initiated to study HIV protease inhibitors such as Lopinavir and Ritonavir. Lopinavir and Ritonavir were initially suspected to inhibit SARS and MERS 3-chymotrypsin-like protease and seemedto be correlated in a non-randomized open-label trial 2, with improved clinical outcomes of SARS patients. It was revealed that Lopinavir and Ritonavir were associated with significant clinical benefit (less adverse clinical outcomes) among SARS$\mathrm{CoV}$ patients [43]. The combination of Lopinavir and Ritonavir is currently a recommended antivirus regimen approved by the National Health Commission of the People's Republic of China in the latest form of Diagnosis and Treatment of Pneumonia Caused by 2019-nCoV (version 5) [44].

\section{ShuFengJieDu Capsule (SFJDC)}

SFJDC is a Traditional Chinese Medicine (TCM), composed of a total of eight medicinal herbs and proven to be clinically effective for the treatment of upper respiratory tract infections, vastly used for influenza diagnosis in China. This medication is also indicated in the current version of Diagnosis and Pneumonia Treatment of 2019-nCoV Infection Caused by COVID-19 [44] and could be possibly screened against 2019-nCoV [43].

\section{Arbidol}


Arbidol is an antiviral drug used in Russia and China to treat influenza infections [45]. Arbidol was reported to have been successful in vitro against 2019-nCoV at a concentration range of 10-30 $\mu \mathrm{M}$ [43]. In China, a randomized multicenter controlled clinical trial of Arbidol was initiated in patients with 2019-nCoV (ChiCTR2000029573) [46] and further studies are in process.

\section{Interferon alfa-2a and alfa-2b}

Pegylated Interferon alfa-2a and alfa-2b, approved for the treatment of Hepatitis B virus (HBV) and Human Coronavirus (HCV), may be used to induce innate antiviral responses in patients infected with 2019-nCoV, and studies involving interferons, such as an approved anti-HCV combination of pegylated interferon plus Ribavirin, have been initiated (ChiCTR2000029387). Whether a pegylated interferon and a nucleoside compound could work synergistically against 2019-nCoV however is unclear. Their assessment should be closely monitored and dose reduction or discontinuation of therapy may be needed due to several adverse effects associated with subcutaneous interferon therapies [37].

\section{Galidesivir}

Galidesivir (BCX4430), an adenosine analog originally developed for human coronavirus (HCV), is currently undergoing early-stage clinical studies examining its protection in healthy subjects and its effectiveness against yellow fever, and has demonstrated antiviral activity in preclinical studies against many RNA viruses, like SARS and MERS2, and possibilities are that facilities with sufficient biocontainment capabilities may screen Galidesivir against 2019-nCoV [13] [15] [37].

\section{Penciclovir}

Penciclovir, a synthetic acyclic guanine derivative, containing antiviral activity, functions as a Herpes Simplex Virus (HSV) DNA inhibitor, is one of the drugs tested against 2019-nCoV. High nucleoside analog concentrations of Penciclovir $(\mathrm{EC} 50=95.96 \mu \mathrm{M}, \mathrm{CC} 50>400 \mu \mathrm{M}, \mathrm{SI}>4.17)$ [10] were needed to reduce the viral infection and could further be examined as a COVID-19 drug [14] [15].

\section{Disulfiram}

Disulfiram, an approved medication for the treatment of alcohol dependence, has been reported to inhibit MERS and SARS papain-like protease in cell cultures but there is no clinical evidence of it. However, it is debatable, whether HIV protease inhibitors could effectively inhibit the 3-chymotrypsin-like, as well as, papain-like proteases of 2019-nCoV, although, Disulfiram could possibly be screened against 2019-nCoV by facilities that have sufficient capabilities of bio-containment [37][47]. 


\section{Griffithsin}

Griffithsin, a lectin derived from red algae, binds on the surface of various viral glycoproteins to oligosaccharides including HIV glycoprotein 120 and SARS-CoV spike glycoprotein2. Griffithsin has low cytotoxicity, is likely to interfere with any coronavirus spike protein due to it is highly glycosylated nature, and may impede the role of coronavirus spike protein. GRFT has been shown to inhibit SARSCoVreplicationand cytopathicity, as well as other coronaviridae viruses [48] [49]. In particular, in Vero 76 cells, GRFT inhibited various strains of SARS - infectionwith a low nanomolar EC50 with limited toxicity on control cells. GRFT can bind with glycans to the surface of the glycoprotein (S protein). A total of three GRFT molecules are capable of binding the $S$ with very high affinity in a dose, a lower number compared to HIV which is presumably due to the lower number of high glycans on the S surface. Interestingly, such an association does not restrict the binding of SARS-CoV S glycoprotein to the human angiotensin I conversion enzyme 2 (ACE2) host cell [49]. Griffithsin has been studied as a gel or enema for HIV prevention in phase I trials, but the efficacy and delivery mechanisms of spike inhibitors should be reevaluated for the 2019-nCoV treatment or prevention.

\section{Cobicistat}

Cobicistat (formerly GS-9350) is a recent pharmacokinetic enhancer with no antiviral function, which still inhibits CYP3A, although more specifically than in vitro Ritonavir [51]. Cobicistat is indicated in conjunction with other antiretroviral agents to increase systemic exposure of atazanavir or darunavir (once daily dosing regimen) in the care of HIV-1 infection. Growing systemic antiretroviral exposure (ARVs) without increasing dose allows for improved patient outcomes and a reduced profile of side effects. In Phase I trials, cobicistat was shown to be a comparable therapeutic enhancer to ritonavir in combination with atazanavir, integrase inhibitor elvitegravir, or midazolam (a CYP3A test substrate) [52]. An atazanavir / cobicistat dependent regimen provided efficacy and protection comparable to an atazanavir / ritonavir regimen in phase II studies [50]. However, a randomized trial at the Shanghai Public Health Clinical Center (SPHCC) evaluating Cobicistat for COVID-19 has shown that it has not been successful and can be reassessed.

\section{Darunavir}

The Chinese authorities have indicated that Darunavir against 2019-nCoV may be successful. In vitro cell studies have shown that Darunavir can effectively inhibit replication of the new strain, at a concentration of 300 micromolar, according to preliminary research Darunavir, in conjunction with cobicistat, will be used in patients with COVID-19 pneumonia in trial number NCT04252274 (50). Such a mixture is currently 
approved by the United States Food and Drug Administration (FDA) in AIDS treatment. Darunavir is another HIV protease inhibitor and cobicistat, like ritonavir, is a booster to enhance the pharmacokinetics and pharmacodynamics of darunavir by inhibiting cytochrome P450 (CYP3A) [53] [54]. Due to in vitro evidence that supports its ability to fight this infection, Darunavir is being studied as a potential cure for SARS-CoV-2, the coronavirus responsible for COVID-19 [52]. Clinical trials are under progress and are scheduled to end in August 2020.

Several registered clinical trials are currently being conducted globally to evaluate the efficacy of the drugs against COVID-19 (Table-1)

Table 1: Ongoing Clinical Trials of Potential Drugs for the Treatment of COVID-19 (Antivirals and Antimalarials)

\begin{tabular}{|c|c|c|c|c|c|}
\hline $\begin{array}{l}\text { Clinical trial ID } \\
\text { No. (Registry) }\end{array}$ & $\begin{array}{c}\text { Intervention to } \\
\text { prevent infection }\end{array}$ & $\begin{array}{l}\text { Participant } \\
\text { size }\end{array}$ & Randomized & Status & $\begin{array}{c}\text { Country } \\
\text { (Pharma.) }\end{array}$ \\
\hline \multicolumn{6}{|c|}{ Antiviral } \\
\hline $\begin{array}{c}\text { 2020-000936-23 } \\
\text { (EU-CTR) }\end{array}$ & $\begin{array}{l}\text { Arm A: } \\
\text { lopinavir/ritonavir } \\
\text { Arm B: interferon } \\
\text { beta 1a } \\
\text { Arm C: } \\
\text { remdesivir }\end{array}$ & 3000 & Yes & Recruiting & France \\
\hline $\begin{array}{c}\text { NCT04302766 } \\
\text { (ClinicalTrials.gov) }\end{array}$ & $\begin{array}{l}\text { Arm A: } \\
\text { remdesivir } \\
\text { Arm B: standard } \\
\text { treatment }\end{array}$ & Unspecified & Unspecified & Available & $\overline{\mathrm{USA}}$ \\
\hline $\begin{array}{c}\text { NCT04292899 } \\
\text { (ClinicalTrials.gov) }\end{array}$ & $\begin{array}{l}\text { Arm A: } \\
\text { remdesivir } \\
\text { Arm B: standard } \\
\text { treatment }\end{array}$ & 400 & Yes & Recruiting & USA \& Asia \\
\hline $\begin{array}{c}\text { NCT04292730 } \\
\text { (ClinicalTrials.gov }\end{array}$ & $\begin{array}{l}\text { Arm A: } \\
\text { remdesivir } \\
\text { Arm B: standard } \\
\text { treatment }\end{array}$ & 600 & Yes & Recruiting & USA \& Asia \\
\hline $\begin{array}{c}\text { NCT04280705 } \\
\text { (ClinicalTrials.gov) }\end{array}$ & $\begin{array}{l}\text { Arm A: } \\
\text { remdesivir }\end{array}$ & 394 & Yes & Recruiting & $\begin{array}{c}\text { USA \& South } \\
\text { Koria }\end{array}$ \\
\hline $\begin{array}{c}2020-000841-15 \\
\text { (EU-CTR) }\end{array}$ & $\begin{array}{l}\text { Arm A: } \\
\text { remdesivir } \\
\text { Arm B: standard } \\
\text { treatment }\end{array}$ & 400 & Yes & Recruiting & Worldwide \\
\hline $\begin{array}{l}\text { 2020-000842-32 } \\
\text { (EU-CTR) }\end{array}$ & $\begin{array}{l}\text { Arm A: } \\
\text { remdesivir } \\
\text { Arm B: standard } \\
\text { treatment }\end{array}$ & 600 & Yes & Recruiting & Worldwide \\
\hline $\begin{array}{c}\text { NCT04252664 } \\
\text { (ClinicalTrials.gov) }\end{array}$ & $\begin{array}{l}\text { Arm A: } \\
\text { remdesivir }\end{array}$ & 308 & Yes & Recruiting & China \\
\hline
\end{tabular}




\begin{tabular}{|c|c|c|c|c|c|}
\hline $\begin{array}{c}\text { NCT04257656 } \\
\text { (ClinicalTrials.gov) }\end{array}$ & $\begin{array}{l}\text { Arm A: } \\
\text { remdesivir }\end{array}$ & 453 & Yes & Recruiting & China \\
\hline $\begin{array}{c}\text { NCT04315948 } \\
\text { (ClinicalTrials.gov) }\end{array}$ & $\begin{array}{l}\text { Arm A: } \\
\text { remdesivir } \\
\text { Arm B: standard } \\
\text { treatment }\end{array}$ & 3100 & Yes & Recruiting & France \\
\hline $\begin{array}{l}\text { ChiCTR2000029600 } \\
\text { (ICTPR) }\end{array}$ & $\begin{array}{l}\text { Arm A: } \\
\text { favipiravir and } \\
\text { interferon alpha } \\
\text { atomisation }\end{array}$ & 90 & No & Recruiting & China \\
\hline $\begin{array}{l}\text { ChiCTR2000029544 } \\
\text { (ICTPR) }\end{array}$ & $\begin{array}{l}\text { Arm A: } \\
\text { favipiravir }\end{array}$ & 30 & Yes & $\begin{array}{c}\text { Not } \\
\text { recruiting }\end{array}$ & China \\
\hline $\begin{array}{l}\text { ChiCTR2000029548 } \\
\text { (ICTPR) }\end{array}$ & $\begin{array}{l}\text { Arm A: } \\
\text { favipiravir }\end{array}$ & 30 & Yes & $\begin{array}{c}\text { Not } \\
\text { recruiting }\end{array}$ & China \\
\hline $\begin{array}{c}\text { NCT04273763 } \\
\text { (ClinicalTrials.gov) }\end{array}$ & $\begin{array}{l}\text { Arm A: } \\
\text { favipiravir and } \\
\text { bromhexine } \\
\text { (mucolytic), } \\
\text { umifenovir, } \\
\text { interferon a2b }\end{array}$ & 60 & Yes & Recruiting & $\begin{array}{c}\text { China } \\
\text { (WanBangDe } \\
\text { Pharm. } \\
\text { Group) }\end{array}$ \\
\hline $\begin{array}{l}\text { ChiCTR2000030113 } \\
\text { (ICTPR) }\end{array}$ & $\begin{array}{l}\text { Arm A: } \\
\text { favipiravir }\end{array}$ & 20 & Yes & Recruiting & China \\
\hline $\begin{array}{l}\text { ChiCTR2000030254 } \\
\text { (ICTPR) }\end{array}$ & $\begin{array}{l}\text { Arm A: } \\
\text { favipiravir }\end{array}$ & 240 & Yes & Recruiting & China \\
\hline $\begin{array}{l}\text { ChiCTR2000030987 } \\
\text { (ICTPR) }\end{array}$ & $\begin{array}{l}\text { Arm A: } \\
\text { favipiravir and } \\
\text { chloroquine } \\
\text { Arm B: } \\
\text { favipiravir }\end{array}$ & 150 & Yes & Recruiting & China \\
\hline $\begin{array}{c}\text { NCT04310228 } \\
\text { (ClinicalTrials.gov) }\end{array}$ & $\begin{array}{l}\text { Arm A: } \\
\text { favipiravir and } \\
\text { tocilizumab } \\
\text { Arm B: } \\
\text { favipiravir }\end{array}$ & 150 & Yes & Recruiting & China \\
\hline $\begin{array}{c}\text { JPRN- } \\
\text { jRCTs041190120 } \\
\text { (ICTPR) }\end{array}$ & $\begin{array}{l}\text { Arm A: } \\
\text { immediate } \\
\text { favipiravir (Day } \\
\text { 1-10) } \\
\text { Arm B: delayed } \\
\text { favipiravir (Day } \\
\text { 6-15) }\end{array}$ & 86 & Yes & Recruiting & Japan \\
\hline $\begin{array}{l}\text { ChiCTR2000029996 } \\
\text { (ICTPR) }\end{array}$ & $\begin{array}{l}\text { Arm A: low-dose } \\
\text { favipiravir } \\
\text { Arm B: medium- } \\
\text { dose favipiravir } \\
\text { Arm C: high-dose } \\
\text { favipiravir }\end{array}$ & 60 & Yes & Recruiting & China \\
\hline $\begin{array}{c}\text { NCT04303299 } \\
\text { (ClinicalTrials.gov) }\end{array}$ & $\begin{array}{l}\text { Arm A: } \\
\text { lopinavir/ritonavir } \\
\text { and favipiravir }\end{array}$ & 80 & Yes & $\begin{array}{c}\text { Not } \\
\text { recruiting }\end{array}$ & Thailand \\
\hline
\end{tabular}




\begin{tabular}{|c|c|c|c|c|c|}
\hline $\begin{array}{c}\text { ChiCTR2000030922 } \\
\text { (ICTPR) }\end{array}$ & $\begin{array}{l}\text { Arm A: ribavirin } \\
\text { and interferon } \\
\text { alpha } 2 \mathrm{a} \\
\text { Arm B: } \\
\text { umifenovir and } \\
\text { ribavirin }\end{array}$ & 30 & Yes & Recruiting & China \\
\hline $\begin{array}{c}\text { NCT04276688 } \\
\text { (ClinicalTrials.gov) }\end{array}$ & $\begin{array}{l}\text { Arm A: ribavirin } \\
+ \\
\text { lopinavir/ritonavir } \\
+ \\
\text { interferon beta } 1 \mathrm{~b}\end{array}$ & 70 & Yes & Recruiting & Hong Kong \\
\hline $\begin{array}{l}\text { ChiCTR2000029387 } \\
\text { (ICTPR) }\end{array}$ & $\begin{array}{l}\text { Arm A: ribavirin } \\
\text { and interferon } \\
\text { alpha-1b } \\
\text { Arm B: ribavirin, } \\
\text { lopinavir/ritonavir, } \\
\text { and } \\
\text { interferon alpha- } \\
\text { lb }\end{array}$ & 108 & Unspecified & Recruiting & China \\
\hline $\begin{array}{c}\text { ChiCTR2000029609 } \\
\text { (ICTPR) }\end{array}$ & $\begin{array}{l}\text { Arm A (mild- } \\
\text { moderate): } \\
\text { chloroquine } \\
\text { Arm B (mild- } \\
\text { moderate): } \\
\text { lopinavir/ritonavir } \\
\text { + chloroquine } \\
\text { Arm C (severe): } \\
\text { chloroquine }\end{array}$ & 205 & No & Recruiting & China \\
\hline $\begin{array}{c}\text { NCT04303299 } \\
\text { (ClinicalTrials.gov) }\end{array}$ & $\begin{array}{l}\text { Arm A: } \\
\text { oseltamivir and } \\
\text { chloroquine }\end{array}$ & 80 & Yes & $\begin{array}{c}\text { Not } \\
\text { recruiting }\end{array}$ & Thailand \\
\hline $\begin{array}{c}\text { IRCT201002280034 } \\
49 \mathrm{~N} 27 \\
\text { (ICTPR) }\end{array}$ & $\begin{array}{l}\text { Arm A: } \\
\text { hydroxychloroqui } \\
\text { ne, lopinavir/ } \\
\text { ritonavir, and } \\
\text { interferon beta } 1 \mathrm{~b} \\
\text { Arm B: } \\
\text { hydroxychloroqui } \\
\text { ne and } \\
\text { lopinavir/ritonavir }\end{array}$ & 30 & Yes & Recruiting & Iran \\
\hline $\begin{array}{c}\text { IRCT201002280034 } \\
\text { 49N28 } \\
\text { (ICTPR) }\end{array}$ & $\begin{array}{l}\text { Arm A: } \\
\text { hydroxychloroqui } \\
\text { ne, lopinavir/ } \\
\text { ritonavir, and } \\
\text { interferon beta 1a } \\
\text { Arm B: } \\
\text { hydroxychloroqui } \\
\text { ne and } \\
\text { lopinavir/ritonavir }\end{array}$ & 30 & Yes & Recruiting & Iran \\
\hline
\end{tabular}




\begin{tabular}{|c|c|c|c|c|c|}
\hline $\begin{array}{c}\text { IRCT2 } 201002280034 \\
49 \mathrm{~N} 29 \\
\text { (ICTPR }\end{array}$ & $\begin{array}{l}\text { Arm A: } \\
\text { hydroxychloroqui } \\
\text { ne, lopinavir/ } \\
\text { ritonavir, and } \\
\text { sofosbuvir/ledipas } \\
\text { vir } \\
\text { Arm B: } \\
\text { hydroxychloroqui } \\
\text { ne and } \\
\text { lopinavir/ritonavir }\end{array}$ & 50 & Yes & Recruiting & Iran \\
\hline $\begin{array}{c}\text { JPRN- } \\
\text { jRCTs031190227 } \\
\text { (ICTPR) }\end{array}$ & $\begin{array}{l}\text { Arm A: } \\
\text { lopinavir/ritonavir } \\
\text { and } \\
\text { hydroxychloroqui } \\
\text { ne }\end{array}$ & 50 & Unspecified & $\begin{array}{c}\text { Not } \\
\text { recruiting }\end{array}$ & Japan \\
\hline $\begin{array}{c}\text { NCT04315948 } \\
\text { (ClinicalTrials.gov) }\end{array}$ & $\begin{array}{l}\text { Arm A: } \\
\text { remdesivir } \\
\text { Arm B: } \\
\text { lopinavir/ritonavir } \\
\text { Arm C: } \\
\text { lopinavir/ritonavir } \\
\text { and interferon } \\
\text { beta 1a } \\
\text { Arm D: } \\
\text { hydroxychloroqui } \\
\text { ne } \\
\text { Arm E: standard } \\
\text { treatment }\end{array}$ & 3100 & Yes & Recruiting & France \\
\hline $\begin{array}{c}\text { NCT04273763 } \\
\text { (ClinicalTrials.gov) }\end{array}$ & $\begin{array}{l}\text { Arm A: } \\
\text { bromhexine } \\
\text { (mucolytic), } \\
\text { umifenovir, } \\
\text { interferon a2b, and } \\
\text { favipiravir } \\
\text { Arm B: } \\
\text { umifenovir and } \\
\text { interferon a2b }\end{array}$ & 60 & Yes & Recruiting & China \\
\hline $\begin{array}{l}\text { ChiCTR2000030254 } \\
\text { (ICTPR) }\end{array}$ & $\begin{array}{l}\text { Arm A: } \\
\text { favipiravir } \\
\text { Arm B: } \\
\text { umifenovir }\end{array}$ & 240 & Yes & Recruiting & China \\
\hline $\begin{array}{c}\text { ChiCTR2000030922 } \\
\text { (ICTPR) }\end{array}$ & $\begin{array}{l}\text { Arm A: interferon } \\
\text { alpha 2a and } \\
\text { ribavirin } \\
\text { Arm B: } \\
\text { umifenovir and } \\
\text { ribavirin }\end{array}$ & 30 & Yes & Recruiting & China \\
\hline $\begin{array}{c}\text { NCT04252885 } \\
\text { (ClinicalTrials.gov) }\end{array}$ & $\begin{array}{l}\text { Arm A: } \\
\text { lopinavir/ritonavir } \\
\text { + basic }\end{array}$ & 125 & Yes & Recruiting & China \\
\hline
\end{tabular}




\begin{tabular}{|c|c|c|c|c|c|}
\hline & $\begin{array}{l}\text { treatment } \\
\text { (unspecified) } \\
\text { Arm B: } \\
\text { umifenovir + basic } \\
\text { treatment } \\
\text { (unspecified) }\end{array}$ & & & & \\
\hline $\begin{array}{c}\text { ChiCTR2000029573 } \\
\text { (ICTPR) }\end{array}$ & $\begin{array}{l}\text { Arm A: } \\
\text { umifenovir } \\
\text { Arm B: } \\
\text { Novaferon and } \\
\text { umifenovir } \\
\text { Arm C: } \\
\text { lopinavir/ritonavir } \\
\text { Arm D: } \\
\text { umifenovir } \\
\text { Arm E: novaferon } \\
\text { and } \\
\text { lopinavir/ritonavir } \\
\text { Arm F: novaferon } \\
\text { and umifenovir }\end{array}$ & 480 & Yes & $\begin{array}{c}\text { Not } \\
\text { recruiting }\end{array}$ & China \\
\hline $\begin{array}{l}\text { ChiCTR2000029621 } \\
\text { (ICTPR) }\end{array}$ & $\begin{array}{l}\text { Arm A: } \\
\text { umifenovir } \\
\text { Arm B: standard } \\
\text { treatment }\end{array}$ & 380 & Yes & Recruiting & China \\
\hline $\begin{array}{c}\text { NCT04254874 } \\
\text { (ClinicalTrials.gov) }\end{array}$ & $\begin{array}{l}\text { Arm A: } \\
\text { umifenovir } \\
\text { Arm B: } \\
\text { umifenovir and } \\
\text { pegylated } \\
\text { interferon alpha } \\
\text { 2b }\end{array}$ & 100 & Yes & Recruiting & China \\
\hline $\begin{array}{c}\text { NCT04255017 } \\
\text { (ClinicalTrials.gov) }\end{array}$ & $\begin{array}{l}\text { Arm A: } \\
\text { umifenovir } \\
\text { Arm B: } \\
\text { oseltamivir } \\
\text { Arm C: } \\
\text { lopinavir/ritonavir }\end{array}$ & 400 & Yes & Recruiting & China \\
\hline $\begin{array}{c}\text { ChiCTR2000029993 } \\
\text { (ICTPR) }\end{array}$ & $\begin{array}{l}\text { Arm A: } \\
\text { umifenovir and } \\
\text { Liushen capsule } \\
\text { Arm B: standard } \\
\text { treatment }\end{array}$ & 40 & Yes & Recruiting & China \\
\hline $\begin{array}{l}\text { ChiCTR2000029592 } \\
\text { (ICTPR) }\end{array}$ & $\begin{array}{l}\text { Arm A: } \\
\text { umifenovir } \\
\text { Arm B: without } \\
\text { umifenovir }\end{array}$ & 100 & Unspecified & $\begin{array}{c}\text { Not } \\
\text { recruiting }\end{array}$ & China \\
\hline $\begin{array}{c}\text { NCT04261270 } \\
\text { (ClinicalTrials.gov) }\end{array}$ & $\begin{array}{l}\text { Arm A: ASC09 } \\
\text { and oseltamivir } \\
\text { Arm B: ritonavir } \\
\text { and oseltamivir }\end{array}$ & 60 & Yes & Recruiting & China \\
\hline
\end{tabular}




\begin{tabular}{|c|c|c|c|c|c|}
\hline & $\begin{array}{l}\text { Arm C: } \\
\text { oseltamivir }\end{array}$ & & & & \\
\hline $\begin{array}{c}\text { NCT04303299 } \\
\text { (ClinicalTrials.gov) }\end{array}$ & $\begin{array}{l}\text { Arm A: } \\
\text { oseltamivir and } \\
\text { chloroquine } \\
\text { Arm B: } \\
\text { lopinavir/ritonavir } \\
\text { and favipiravir } \\
\text { Arm C: } \\
\text { lopinavir/ritonavir } \\
\text { and oseltamivir } \\
\text { Arm D: } \\
\text { lopinavir/ritonavir } \\
\text { and oseltamivir }\end{array}$ & 80 & Yes & $\begin{array}{c}\text { Not } \\
\text { recruiting }\end{array}$ & Thailand \\
\hline $\begin{array}{c}\text { ChiCTR2000029609 } \\
\text { (ICTPR) }\end{array}$ & $\begin{array}{l}\text { Arm A (mild- } \\
\text { moderate): } \\
\text { lopinavir/ritonavir } \\
\text { Arm B (mild- } \\
\text { moderate): } \\
\text { lopinavir/ritonavir } \\
\text { + chloroquine } \\
\text { Arm C (severe): } \\
\text { lopinavir/ritonavir }\end{array}$ & 205 & Yes & Recruiting & China \\
\hline $\begin{array}{l}\text { ChiCTR2000029600 } \\
\text { (ICTPR) }\end{array}$ & $\begin{array}{l}\text { Arm A: interferon } \\
\text { alpha atomisation } \\
\text { Arm B: } \\
\text { lopinavir/ritonavir } \\
\text { and interferon } \\
\text { alpha atomisation }\end{array}$ & 90 & No & Recruiting & China \\
\hline $\begin{array}{c}\text { NCT04261907 } \\
\text { (ClinicalTrials.gov) }\end{array}$ & $\begin{array}{l}\text { Arm A: } \\
\text { ASC09/ritonavir } \\
\text { Arm B: } \\
\text { lopinavir/ritonavir }\end{array}$ & 160 & Yes & Recruiting & $\begin{array}{c}\text { China } \\
\text { (Ascletis } \\
\text { Pharm) }\end{array}$ \\
\hline $\begin{array}{l}\text { ChiCTR2000029548 } \\
\text { (ICTPR) }\end{array}$ & $\begin{array}{l}\text { Arm A: baloxavir } \\
\text { marboxil } \\
\text { Arm B: } \\
\text { favipiravir } \\
\text { Arm C: } \\
\text { lopinavir/ritonavir }\end{array}$ & 30 & Yes & $\begin{array}{c}\text { Not } \\
\text { recruiting }\end{array}$ & China \\
\hline $\begin{array}{l}\text { ChiCTR2000029541 } \\
\text { (ICTPR) }\end{array}$ & $\begin{array}{l}\text { Arm A: } \\
\text { darunavir/cobicist } \\
\text { at and } \\
\text { thymosin } \\
\text { Arm B: } \\
\text { lopinavir/ritonavir } \\
\text { and thymosin } \\
\text { Arm C: thymosin }\end{array}$ & 100 & Yes & $\begin{array}{c}\text { Not } \\
\text { recruiting }\end{array}$ & China \\
\hline $\begin{array}{c}\text { NCT04291729 } \\
\text { (ClinicalTrials.gov) }\end{array}$ & $\begin{array}{l}\text { Arm A: } \\
\text { darunavir/ritonavir } \\
\text { and }\end{array}$ & 50 & Yes & Recruiting & $\begin{array}{l}\text { China } \\
\text { (Ascletis } \\
\text { Pharm) }\end{array}$ \\
\hline
\end{tabular}




\begin{tabular}{|c|c|c|c|c|c|}
\hline & $\begin{array}{l}\text { atomised } \\
\text { interferon } \\
\text { Arm B: } \\
\text { peginterferon a2 } \\
\text { Arm C: interferon } \\
\text { alpha (Novaferon) } \\
\text { Arm D: } \\
\text { lopinavir/ritonavir } \\
\text { Arm E: atomised } \\
\text { interferon + } \\
\text { Chinese } \\
\text { medicine } \\
\text { (unspecified) }\end{array}$ & & & & \\
\hline $\begin{array}{c}\text { ChiCTR2000030535 } \\
\text { (ICTPR) }\end{array}$ & $\begin{array}{l}\text { Arm A: ebastine } \\
\text { and interferon } \\
\text { alpha } \\
\text { inhalation and } \\
\text { lopinavir } \\
\text { Arm B: interferon } \\
\text { alpha inhalation } \\
\text { and } \\
\text { lopinavir }\end{array}$ & 100 & Yes & Recruiting & China \\
\hline $\begin{array}{l}\text { 2020-001113-21 } \\
\text { (EU-CTR) }\end{array}$ & $\begin{array}{l}\text { Arm A: } \\
\text { lopinavir/ritonavir } \\
\text { Arm B: } \\
\text { dexamethasone } \\
\text { Arm C: interferon } \\
\text { beta 1a } \\
\text { Arm D: placebo }\end{array}$ & 2000 & Yes & Recruiting & UK \\
\hline $\begin{array}{c}\text { ChiCTR2000029468 } \\
\text { (ICTPR) }\end{array}$ & $\begin{array}{l}\text { Arm A: } \\
\text { lopinavir/ritonavir } \\
\text { and } \\
\text { emtricitabine/teno } \\
\text { fovir } \\
\text { Arm B: } \\
\text { lopinavir/ritonavir }\end{array}$ & 120 & Unspecified & $\begin{array}{l}\text { Not } \\
\text { recruiting }\end{array}$ & China \\
\hline $\begin{array}{l}\text { ChiCTR2000030166 } \\
\text { (ICTPR) }\end{array}$ & $\begin{array}{l}\text { Arm A: } \\
\text { lopinavir/ritonavir } \\
\text { and interferon } \\
\text { alpha 2b and } \\
\text { Qing-Wen Bai- } \\
\text { Du-Yin } \\
\text { granules } \\
\text { Arm B: } \\
\text { lopinavir/ritonavir } \\
\text { and interferon } \\
\text { alpha 2b }\end{array}$ & 20 & Yes & $\begin{array}{c}\text { Not } \\
\text { recruiting }\end{array}$ & China \\
\hline $\begin{array}{c}\text { ChiCTR2000030218 } \\
\text { (ICTPR) }\end{array}$ & $\begin{array}{l}\text { Arm A: } \\
\text { lopinavir/ritonavir } \\
\text { and }\end{array}$ & 80 & Unspecified & Recruiting & China \\
\hline
\end{tabular}




\begin{tabular}{|c|c|c|c|c|c|}
\hline & $\begin{array}{l}\text { Xiyanping } \\
\text { injection } \\
\text { Arm B: ritonavir }\end{array}$ & & & & \\
\hline $\begin{array}{l}\text { ChiCTR2000029539 } \\
\text { (ICTPR) }\end{array}$ & $\begin{array}{l}\text { Arm A: } \\
\text { lopinavir/ritonavir } \\
\text { Arm B: standard } \\
\text { treatment }\end{array}$ & 328 & Yes & Recruiting & China \\
\hline $\begin{array}{l}\text { ChiCTR2000029496 } \\
\text { (ICTPR) }\end{array}$ & $\begin{array}{l}\text { Arm A: } \\
\text { Novaferon } \\
\text { atomisation } \\
\text { inhalation } \\
\text { Arm B: } \\
\text { lopinavir/ritonavir } \\
\text { Arm C: } \\
\text { Novaferon and } \\
\text { lopinavir/ritonavir }\end{array}$ & 90 & Yes & Recruiting & China \\
\hline $\begin{array}{c}\text { NCT04252274 } \\
\text { (ClinicalTrials.gov) }\end{array}$ & $\begin{array}{l}\text { Arm A: darunavir } \\
\text { and cobicistat } \\
\text { Arm B: standard } \\
\text { treatment }\end{array}$ & 30 & Yes & Recruiting & China \\
\hline $\begin{array}{c}\text { NCT04304053 } \\
\text { (ClinicalTrials.gov) }\end{array}$ & $\begin{array}{l}\text { Arm A: } \\
\text { darunavir/cobicist } \\
\text { at } \\
\text { Arm B: isolation }\end{array}$ & 3040 & Yes & Recruiting & Spain \\
\hline \multicolumn{6}{|c|}{ Antimalarial } \\
\hline $\begin{array}{l}\text { ChiCTR2000030031 } \\
\text { (ICTPR) }\end{array}$ & $\begin{array}{l}\text { Arm A: } \\
\text { chloroquine }\end{array}$ & 120 & Yes & Recruiting & China \\
\hline $\begin{array}{l}\text { ChiCTR2000029988 } \\
\text { (ICTPR) }\end{array}$ & $\begin{array}{l}\text { Arm A: } \\
\text { chloroquine } \\
\text { Arm B: standard } \\
\text { treatment }\end{array}$ & 80 & Unspecified & Recruiting & China \\
\hline $\begin{array}{c}\text { ChiCTR2000029939 } \\
\text { (ICTPR) }\end{array}$ & $\begin{array}{l}\text { Arm A: } \\
\text { chloroquine } \\
\text { Arm B: standard } \\
\text { treatment }\end{array}$ & 100 & Yes & Recruiting & China \\
\hline $\begin{array}{c}\text { ChiCTR2000029975 } \\
\text { (ICTPR) }\end{array}$ & $\begin{array}{l}\text { Arm A: } \\
\text { chloroquine }\end{array}$ & 10 & No & $\begin{array}{c}\text { Not } \\
\text { recruiting }\end{array}$ & China \\
\hline $\begin{array}{c}\text { ChiCTR2000029837 } \\
\text { (ICTPR) }\end{array}$ & $\begin{array}{l}\text { Arm A: } \\
\text { chloroquine }\end{array}$ & 120 & Yes & $\begin{array}{c}\text { Not } \\
\text { recruiting }\end{array}$ & China \\
\hline $\begin{array}{c}\text { ChiCTR2000029935 } \\
\text { (ICTPR) }\end{array}$ & $\begin{array}{l}\text { Arm A: } \\
\text { chloroquine }\end{array}$ & 100 & No & Recruiting & China \\
\hline $\begin{array}{l}\text { ChiCTR2000029542 } \\
\text { (ICTPR }\end{array}$ & $\begin{array}{l}\text { Arm A: } \\
\text { chloroquine } \\
\text { Arm B: standard } \\
\text { treatment }\end{array}$ & 20 & Unspecified & Recruiting & China \\
\hline $\begin{array}{l}\text { ChiCTR2000030718 } \\
\text { (ICTPR) }\end{array}$ & $\begin{array}{l}\text { Arm A: } \\
\text { chloroquine } \\
\text { Arm B: standard } \\
\text { treatment }\end{array}$ & 80 & Yes & Recruiting & China \\
\hline
\end{tabular}




\begin{tabular}{|c|c|c|c|c|c|}
\hline $\begin{array}{l}\text { ChiCTR2000029898 } \\
\text { (ICTPR) }\end{array}$ & $\begin{array}{l}\text { Arm A: } \\
\text { hydroxychloroqui } \\
\text { ne } \\
\text { Arm B: } \\
\text { chloroquine }\end{array}$ & 100 & Yes & Recruiting & China \\
\hline $\begin{array}{c}\text { NCT04261517 } \\
\text { (ClinicalTrials.gov) }\end{array}$ & $\begin{array}{l}\text { Arm A: } \\
\text { hydroxychloroqui } \\
\text { ne } \\
\text { Arm B: standard } \\
\text { of care }\end{array}$ & 30 & Yes & Recruiting & China \\
\hline $\begin{array}{l}\text { ChiCTR2000030054 } \\
\text { (ICTPR }\end{array}$ & $\begin{array}{l}\text { Arm A: } \\
\text { hydroxychloroqui } \\
\text { ne } \\
\text { Arm B: standard } \\
\text { treatment }\end{array}$ & 100 & Yes & $\begin{array}{c}\text { Not } \\
\text { recruiting }\end{array}$ & China \\
\hline $\begin{array}{l}\text { ChiCTR2000029868 } \\
\text { (ICTPR) }\end{array}$ & $\begin{array}{l}\text { Arm A: } \\
\text { hydroxychloroqui } \\
\text { ne } \\
\text { Arm B: standard } \\
\text { treatment }\end{array}$ & 200 & Yes & Recruiting & China \\
\hline $\begin{array}{l}\text { ChiCTR2000029740 } \\
\text { (ICTPR }\end{array}$ & $\begin{array}{l}\text { Arm A: } \\
\text { hydroxychloroqui } \\
\text { ne } \\
\text { Arm B: standard } \\
\text { treatment }\end{array}$ & 78 & Yes & Recruiting & China \\
\hline $\begin{array}{c}\text { ChiCTR2000029899 } \\
\text { (ICTPR) }\end{array}$ & $\begin{array}{l}\text { Arm A: } \\
\text { hydroxychloroqui } \\
\text { ne } \\
\text { Arm B: } \\
\text { chloroquine }\end{array}$ & 100 & Yes & Recruiting & China \\
\hline $\begin{array}{c}\text { NCT04316377 } \\
\text { (ClinicalTrials.gov) }\end{array}$ & $\begin{array}{l}\text { Arm A: } \\
\text { hydroxychloroqui } \\
\text { ne } \\
\text { Arm B: standard } \\
\text { treatment }\end{array}$ & 202 & Yes & $\begin{array}{c}\text { Not } \\
\text { recruiting }\end{array}$ & Norway \\
\hline $\begin{array}{c}\text { NCT04315896 } \\
\text { (ClinicalTrials.gov) }\end{array}$ & $\begin{array}{l}\text { Arm A: } \\
\text { hydroxychloroqui } \\
\text { ne } \\
\text { Arm B: placebo }\end{array}$ & 500 & Yes & $\begin{array}{c}\text { Not } \\
\text { recruiting }\end{array}$ & Mexico \\
\hline $\begin{array}{c}\text { ChiCTR2000029559 } \\
\text { (ICTPR) }\end{array}$ & $\begin{array}{l}\text { Arm A: } \\
\text { hydroxychloroqui } \\
\text { ne } \\
\text { Arm B: } \\
\text { hydroxychloroqui } \\
\text { ne }\end{array}$ & 300 & Unspecified & Recruiting & China \\
\hline $\begin{array}{l}\text { ChiCTR2000029803 } \\
\text { (ICTPR) }\end{array}$ & $\begin{array}{l}\text { Arm A: } \\
\text { hydroxychloroqui } \\
\text { ne (low dose) }\end{array}$ & 320 & Yes & $\begin{array}{c}\text { Not } \\
\text { recruiting }\end{array}$ & China \\
\hline
\end{tabular}




\begin{tabular}{|c|l|c|c|c|c|}
\hline & $\begin{array}{l}\text { Arm B: } \\
\text { hydroxychloroqui } \\
\text { ne (high dose) }\end{array}$ & & & \\
\hline $\begin{array}{c}\text { ChiCTR2000030082 } \\
\text { (ICTPR) }\end{array}$ & $\begin{array}{l}\text { Arm A: } \\
\text { dihydroartemisini } \\
\text { n/ } \\
\text { piperaquine tablets } \\
\text { combined with } \\
\text { antiviral treatment } \\
\text { (presumed } \\
\text { alpha-interferon } \\
\text { umifenovir) } \\
\text { Arm B: alpha- } \\
\text { interferon + } \\
\text { umifenovir }\end{array}$ & 40 & Yes & Suspended & China \\
\hline $\begin{array}{c}\text { Arm A: } \\
\text { umifenovir (low } \\
\text { dose) } \\
\text { Arm B: } \\
\text { umifenovir (high } \\
\text { dose) }\end{array}$ & 320 & Yes & Not & \\
(ICTPR) & & & & \\
& & & & \\
\hline
\end{tabular}

\section{Conclusion}

It is a pivotal time in overcoming the current outbreak of the 2019-nCoV. The decoction of the specified drugs listed should be assessed for their efficacy and safety and stability, and should also be evaluated for the treatment and recovery of patients suffering from the 2019-nCoV in carefully planned clinical trials, either used alone or integrated with other drugs. Many of the potential drugs under different phases of clinical trials (eg: Remdesivir, Lopinavir, Ritonavir, Darunavir, Cobicistat etc. are in phase III, Oseltamivir is in phase IV of clinical trials, and many others are in preclinical stage of trials) can be successful in battling COVID-19 [10][37][43][47]. The vital ethical concern in the COVID-19 setting for the administration of repurposable drugs are experimental and, thus, require ethical or off-label approval of trials [55]. We will keep cautiously optimistic before releasing successful clinical trial results as the lessons from a recent public panic buying spree, which revealed results of a preliminary study and induced irrational purchases overnight, should also be taken into account. In this study, our approach will reduce the translational gap between preclinical research results and clinical outcomes, which is a major problem in the rapid production of successful drugs, discovered for the emerging 2019-nCoV / SARS-CoV-2 outbreak. 


\section{Declaration of competing interest}

The authors declare no conflicts of interest.

\section{Author contributions}

\begin{tabular}{|l|l|l|l|l|l|l|l|}
\hline Authors & $\begin{array}{l}\text { Conceptuali } \\
\text { zation }\end{array}$ & $\begin{array}{l}\text { Data } \\
\text { Curation }\end{array}$ & Resources & $\begin{array}{l}\text { Original } \\
\text { draft } \\
\text { writing }\end{array}$ & Citation & $\begin{array}{l}\text { Editing and } \\
\text { approval of } \\
\text { final article }\end{array}$ & Supervision \\
\hline F.B.Mina & Yes & Yes & Yes & Yes & Yes & Yes & No \\
\hline M.S.Rahman & Yes & Yes & Yes & No & No & Yes & No \\
\hline S.Das & Yes & Yes & Yes & No & Yes & No & No \\
\hline S.Karmakar & Yes & No & No & No & No & Yes & Yes \\
\hline M.Billah & Yes & Yes & No & No & Yes & Yes & Yes \\
\hline
\end{tabular}

\section{Funding}

None of the authors has any financial supports to complete the content of the manuscript.

\section{References}

[1] Li, G., Fan, Y., Lai, Y., Han, T., Li, Z., Zhou, P., \& Zhang, Q. (2020). Coronavirus infections and immune responses. Journal of medical virology, 92(4), 424-432.

[2] https://www.worldometers.info/coronavirus/coronavirus-death-toll/

[3] Ahmed, S. F., Quadeer, A. A., \& McKay, M. R. (2020). Preliminary identification of potential vaccine targets for the COVID-19 coronavirus (SARS-CoV-2) based on SARS-CoV immunological studies. Viruses, 12(3), 254.

[4] Raj, V. S., Mou, H., Smits, S. L., Dekkers, D. H., Müller, M. A., Dijkman, R., \& Thiel, V. (2013). Dipeptidyl peptidase 4 is a functional receptor for the emerging human coronavirusEMC. Nature, 495(7440), 251-254. 
[5] Shanmugaraj, B., Siriwattananon, K., Wangkanont, K., \& Phoolcharoen, W. (2020). Perspectives on monoclonal antibody therapy as potential therapeutic intervention for Coronavirus disease-19 (COVID19). Asian Pacific Journal of Allergy and Immunology, 38(1), 10-18.

[6] Du, L., Yang, Y., Zhou, Y., Lu, L., Li, F., \& Jiang, S. (2017). MERS-CoV spike protein: a key target for antivirals. Expert opinion on therapeutic targets, 21(2), 131-143.

[7] Kruse, R. L. (2020). Therapeutic strategies in an outbreak scenario to treat the novel coronavirus originating in Wuhan, China. F1000Research, 9.

[8] Jin, Y. H., Cai, L., Cheng, Z. S., Cheng, H., Deng, T., Fan, Y. P., \& Han, Y. (2020). A rapid advice guideline for the diagnosis and treatment of 2019 novel coronavirus (2019-nCoV) infected pneumonia (standard version). Military Medical Research, 7(1), 4.

[9] Zhou, Y., Hou, Y., Shen, J., Huang, Y., Martin, W., \& Cheng, F. (2020). Network-based drug repurposing for novel coronavirus 2019-nCoV/SARS-CoV-2. Cell Discovery, 6(1), 1-18.

[10] Wang, M. et al. Remdesivir and chloroquine effectively inhibit the recently emerged novel coronavirus (2019-nCoV) in vitro. Cell Res. https://doi.org/10.1038/s41422-020-0282-0 (2020).

[11] Holshue, M. L., DeBolt, C., Lindquist, S., Lofy, K. H., Wiesman, J., Bruce, H., \& Diaz, G. (2020). First case of 2019 novel coronavirus in the United States. New England Journal of Medicine.

[12] Zhou, P., Yang, X. L., Wang, X. G., Hu, B., Zhang, L., Zhang, W., \& Chen, H. D. (2020). A pneumonia outbreak associated with a new coronavirus of probable bat origin. Nature, 579(7798), 270-273.

[13] De Clercq, E. (2019). New Nucleoside Analogues for the Treatment of Hemorrhagic Fever Virus Infections. Chemistry-An Asian Journal, 14(22), 3962-3968.

[14] Oestereich, L., Lüdtke, A., Wurr, S., Rieger, T., Muñoz-Fontela, C., \& Günther, S. (2014). Successful treatment of advanced Ebola virus infection with T-705 (favipiravir) in a small animal model. Antiviral research, 105, 17-21.

[15] Zumla, A., Chan, J. F., Azhar, E. I., Hui, D. S., \& Yuen, K. Y. (2016). Coronaviruses-drug discovery and therapeutic options. Nature reviews Drug discovery, 15(5), 327.

[16] Canonico, P. G., Jahrling, P. B., \& Pannier, W. L. (1982). Antiviral efficacy of pyrazofurin against selected RNA viruses. Antiviral research, 2(6), 331-337. 
[17] Buchanan, J. G. (1983). The C-nucleoside antibiotics. In Fortschritte der Chemie organischer Naturstoffe/Progress in the Chemistry of Organic Natural Products (pp. 243-299). Springer, Vienna.

[18] Hacksell, U., \& Daves Jr, G. D. (1985). 1 The Chemistry and Biochemistry of C-Nucleosides and CArylglycosides. In Progress in medicinal chemistry (Vol. 22, pp. 1-65). Elsevier.

[19] De Clercq, E. (2009). Another ten stories in antiviral drug discovery (part C):“old" and "new" antivirals, strategies, and perspectives. Medicinal research reviews, 29(4), 611-645.

[20] De Clercq, E. (2015). Curious (old and new) antiviral nucleoside analogues with intriguing therapeutic potential. Current medicinal chemistry, 22(34), 3866-3880.

[21] De Clercq, E. (2016). C-Nucleosides to be revisited: Miniperspective. Journal of medicinal chemistry, 59(6), 2301-2311.

[22] Ren, D., Wang, S. A., Ko, Y., Geng, Y., Ogasawara, Y., \& Liu, H. W. (2019). Identification of the CGlycoside Synthases during Biosynthesis of the Pyrazole-C-Nucleosides Formycin and Pyrazofurin. Angewandte Chemie International Edition, 58(46), 16512-16516.

[23] Savarino, A., Di Trani, L., Donatelli, I., Cauda, R., \& Cassone, A. (2006). New insights into the antiviral effects of chloroquine. The Lancet infectious diseases, 6(2), 67-69.

[24] Yan, Y., Zou, Z., Sun, Y., Li, X., Xu, K. F., Wei, Y., \& Jiang, C. (2013). Anti-malaria drug chloroquine is highly effective in treating avian influenza A $\mathrm{H} 5 \mathrm{~N} 1$ virus infection in an animal model. Cell research, 23(2), 300-302.

[25] Vincent, M. J., Bergeron, E., Benjannet, S., Erickson, B. R., Rollin, P. E., Ksiazek, T. G., \& Nichol, S. T. (2005). Chloroquine is a potent inhibitor of SARS coronavirus infection and spread. Virology journal, 2(1), 69.

[26] Liu, W., Morse, J. S., Lalonde, T., \& Xu, S. (2020). Learning from the past: possible urgent prevention and treatment options for severe acute respiratory infections caused by 2019-nCoV. Chembiochem.

[27] Cortegiani, A., Ingoglia, G., Ippolito, M., Giarratano, A., \& Einav, S. (2020). A systematic review on the efficacy and safety of chloroquine for the treatment of COVID-19. Journal of Critical Care.

[28] Colson, P., Rolain, J. M., Lagier, J. C., Brouqui, P., \& Raoult, D. (2020). Chloroquine and hydroxychloroquine as available weapons to fight COVID-19. Int J Antimicrob Agents, 105932. 
[29] Yao, X., Ye, F., Zhang, M., Cui, C., Huang, B., Niu, P., \& Zhan, S. (2020). In vitro antiviral activity and projection of optimized dosing design of hydroxychloroquine for the treatment of severe acute respiratory syndrome coronavirus 2 (SARS-CoV-2). Clinical Infectious Diseases.

[30] Gurwitz, D. (2020). Angiotensin receptor blockers as tentative SARS-CoV-2 therapeutics. Drug development research.

[31] Li, G., Hu, R., \& Zhang, X. (2020). Antihypertensive treatment with ACEI/ARB of patients with COVID-19 complicated by hypertension. Hypertension Research, 1-3.

[32] Li, W., Moore, M. J., Vasilieva, N., Sui, J., Wong, S. K., Berne, M. A., \& Choe, H. (2003). Angiotensin-converting enzyme 2 is a functional receptor for the SARS coronavirus. Nature, 426(6965), 450-454.

[33] Cheng, H., Wang, Y., \& Wang, G. Q. (2020). Organ-protective Effect of Angiotensin-converting Enzyme 2 and its Effect on the Prognosis of COVID-19. Journal of Medical Virology.

[34] Voiriot, G., Philippot, Q., Elabbadi, A., Elbim, C., Chalumeau, M., \& Fartoukh, M. (2019). Risks Related to the Use of Non-Steroidal Anti-Inflammatory Drugs in Community-Acquired Pneumonia in Adult and Pediatric Patients. Journal of clinical medicine, 8(6), 786.

[35] Little, P. (2020). Non-steroidal anti-inflammatory drugs and covid-19. BMJ (Clinical research ed.), $368, \mathrm{~m} 1185$.

[36] Little, P., Moore, M., Kelly, J., Williamson, I., Leydon, G., McDermott, L., \& Stuart, B. (2013). Ibuprofen, paracetamol, and steam for patients with respiratory tract infections in primary care: pragmatic randomised factorial trial. Bmj, 347, f6041.

[37] Li, G., \& De Clercq, E. (2020). Therapeutic options for the 2019 novel coronavirus (2019-nCoV). Nature reviews. Drug discovery, 19(3), 149.

[38] Haviernik, J., Štefánik, M., Fojtíková, M., Kali, S., Tordo, N., Rudolf, I., \& Ruzek, D. (2018). Arbidol (Umifenovir): a broad-spectrum antiviral drug that inhibits medically important arthropod-borne flaviviruses. Viruses, 10(4), 184.

[39] https://www.drugtargetreview.com/news/58915/nafamostat-inhibits-sars-cov-2-infection preventingcovid19transmission/fbclid 
[40] Debar, S., Kumarapeli, P., Kaski, J. C., \& De Lusignan, S. (2010). Addressing modifiable risk factors for coronary heart disease in primary care: an evidence-base lost in translation. Family practice, 27(4), $370-378$.

[41] Stellbrink, H. J., Arastéh, K., Schürmann, D., Stephan, C., Dierynck, I., Smyej, I., \& Mariën, K. (2014). Antiviral Activity, Pharmacokinetics, and Safety of the HIV-1 Protease Inhibitor TMC310911, Coadministered With Ritonavir, in Treatment-Naive HIV-1-Infected Patients. JAIDS Journal of Acquired Immune Deficiency Syndromes, 65(3), 283-289.

[42] Harrison, C. (2020). Coronavirus puts drug repurposing on the fast track. Nature biotechnology.

[43] Wang, Z., Chen, X., Lu, Y., Chen, F., \& Zhang, W. (2020). Clinical characteristics and therapeutic procedure for four cases with 2019 novel coronavirus pneumonia receiving combined Chinese and Western medicine treatment. Bioscience trends.

[44] Chu, C. M., Cheng, V. C. C., Hung, I. F. N., Wong, M. M. L., Chan, K. H., Chan, K. S., \& Peiris, J. S. M. (2004). Role of lopinavir/ritonavir in the treatment of SARS: initial virological and clinical findings. Thorax, 59(3), 252-256.

[45] Teissier, E., Zandomeneghi, G., Loquet, A., Lavillette, D., Lavergne, J. P., Montserret, R., \& Pécheur, E. I. (2011). Mechanism of inhibition of enveloped virus membrane fusion by the antiviral drug arbidol. PloS one, 6(1).

[46] Wang, Y., Ding, Y., Yang, C., Li, R., Du, Q., Hao, Y., \& Yang, Z. (2017). Inhibition of the infectivity and inflammatory response of influenza virus by Arbidol hydrochloride in vitro and in vivo (mice and ferret). Biomedicine \& Pharmacotherapy, 91, 393-401.

[47] Dong, L., Hu, S., \& Gao, J. (2020). Discovering drugs to treat coronavirus disease 2019 (COVID19). Drug Discoveries \& Therapeutics, 14(1), 58-60.

[48] Ziółkowska, N. E., O'Keefe, B. R., Mori, T., Zhu, C., Giomarelli, B., Vojdani, F., \& Wlodawer, A. (2006). Domain-swapped structure of the potent antiviral protein griffithsin and its mode of carbohydrate binding. Structure, 14(7), 1127-1135.

[49] O'Keefe, B. R., Giomarelli, B., Barnard, D. L., Shenoy, S. R., Chan, P. K., McMahon, J. B., \& McCray, P. B. (2010). Broad-spectrum in vitro activity and in vivo efficacy of the antiviral protein griffithsin against emerging viruses of the family Coronaviridae. Journal of virology, 84(5), 2511-2521. 
[50] Kakuda, T. N., Crauwels, H., Opsomer, M., Tomaka, F., van de Casteele, T., Vanveggel, S., \& de Smedt, G. (2015). Darunavir/cobicistat once daily for the treatment of HIV. Expert review of antiinfective therapy, 13(6), 691-704.

[51] Gallant, J. E., Koenig, E., Andrade-Villanueva, J., Chetchotisakd, P., DeJesus, E., Antunes, F., \& Liu, Y. (2013). Cobicistat versus ritonavir as a pharmacoenhancer of atazanavir plus emtricitabine/tenofovir disoproxil fumarate in treatment-naive HIV type 1-infected patients: week 48 results. The Journal of infectious diseases, 208(1), 32-39.

[52] Elion, R., Cohen, C., Gathe, J., Shalit, P., Hawkins, T., Liu, H. C., \& Warren, D. R. (2011). Phase 2 study of cobicistat versus ritonavir each with once-daily atazanavir and fixed-dose emtricitabine/tenofovir df in the initial treatment of HIV infection. Aids, 25(15), 1881-1886.

[53] Santos, J. R., Curran, A., Navarro-Mercade, J., Ampuero, M. F., Pelaez, P., Pérez-Alvarez, N., \& Moltó, J. (2019). Simplification of antiretroviral treatment from darunavir/ritonavir monotherapy to darunavir/cobicistat monotherapy: effectiveness and safety in routine clinical practice. AIDS research and human retroviruses, 35(6), 513-518.

[54] Mathias, A. A., German, P., Murray, B. P., Wei, L., Jain, A., West, S., \& Kearney, B. P. (2010). Pharmacokinetics and pharmacodynamics of GS-9350: a novel pharmacokinetic enhancer without anti-HIV activity. Clinical Pharmacology \& Therapeutics, 87(3), 322-329.

[55] Momattin, H., Al-Ali, A. Y., \& Al-Tawfiq, J. A. (2019). A Systematic Review of therapeutic agents for the treatment of the Middle East Respiratory Syndrome Coronavirus (MERS-CoV). Travel medicine and infectious disease, 30, 9-18. 